\title{
DETECTION AND GENOTYPING OF CLASSICAL SWINE FEVER VIRUS ISOLATES IN SERBIA
}

\author{
MILIĆEVIĆ VESNA*, RADOJIČIĆ SONJA**, VALČIĆ AM**, IVOVIĆ V***, \\ MAKSIMOVIĆ-ZORIĆ JELENA* and RADOSAVLJEVIĆ $V * *$ \\ *Institute of Veterinary Medicine of Serbia, Belgrade, Serbia \\ **University of Belgrade, Faculty of Veterinary medicine, Belgrade, Serbia \\ ${ }^{* * *}$ Centre for Parasitic Zoonoses, Institute for Medical Research, Belgrade, Serbia
}

$$
\text { (Received 15 }{ }^{\text {th }} \text { September 2012) }
$$

Classical swine fever (CSF) is a highly contagious disease of pigs leading to significant economic losses worldwide. Classical swine fever virus can be classified into three genogroups, each consisting of three or four subgroups. However, there is a lack of knowledge on the genotypes of CSFV isolates in Republic of Serbia. This study, based on the sequences analysis of partial E2 gene and $5^{\prime}$ non coding region (NCR) of 15 CSFV isolated during 2006-2008 from domestic pigs, revealed that all were clustered into genetic group 2.3. Additionally, we showed that the two most often used real time RT-PCR assays were able to detect all local CSF viruses circulated in Serbia in the last years during intensive vaccination campaign against CSF.

Key words: Classical swine fever virus, genotyping, real time RTPCR, Serbia

\section{INTRODUCTION}

Classical swine fever (CSF) is often fatal and highly contagious multisystemic disease of pigs (Edwards, 2000). It is caused by the Classical Swine Fever Virus (CSFV), a member of the family Flaviviridae, genus Pestivirus (Heinz et al., 2000). CSV virus is enveloped and its genome is composed of single-stranded RNA of positive polarity (Meyers et al., 1989). Natural hosts of CSFV are domestic pigs and wild boars (Blome et al., 2010). Infection usually occurs via oronasal route although other rutes are also possible (Paton and Greiser-Wilke, 2003). After the primary replication in the epithelial crypts of the tonsil, the virus may be carried to local lymph nodes and into the bloodstream causing a severe leucopoenia, immunosuppression, widespread thrombosis and endothelial damage (Paton and Greiser-Wilke, 2003). The disease severity depends on the age and, probably, the breed of the pigs, the virulence of the virus and some other, still unidentified factors (Paton and Greiser-Wilke, 2003). The disease appears in the classic form characterized by high fever, generalized illness, hemorrhagic lesions, immunosuppression, pronounced lymphocytopenia and a high mortality, as well as in the chronic course and "late onset" form which is of great importance as far 
as virus surviving and maintaining in nature are concerned (Thiel et al., 1996). Considering that CSFV easily passes through the placental barrier (Dewulf et al., 2001), infection of fetuses is common in pregnant sows. The outcome of foetal infection depends on the gestation stage and virulence of the virus (Moennig and Plagemann, 1992).

CSF is widespread throughout the world. The greatest virus diversity is seen in Asia where CSF is endemic while the situation in Africa is uncertain (Paton and Greiser-Wilke, 2003). Australia, North America and most of Europe are CSF free (Paton and Greiser-Wilke, 2003). However, EU Member States have been periodically experiencing reintroduction of CSFV into domestic pigs via wild boars (Greiser-Wilke et al., 2000). Based on the nucleotide sequences of at least two regions, 5'NCR and partial E2 coding gene, CSF viruses can be divided into 3 genetic groups and several subgroups whereas only one serotype has been found (Blome et al., 2010).

It has been shown that almost all analyzed viruses isolated in Europe during the period 1920-1970 cluster in Group 1. Most of them are of subgroup 1.1. Subgroup 1.2. was found in Brescia, Italy, while no subgroup 1.3 viruses have been identified in Europe (Paton et al., 2000). Nevertheless, in 1970 group 1 has been very rarely reported in Europe. In the following years, a genetic shift from group 1 to group 2 was observed throughout Europe, with evident prevalence of the 2.3 subgroup (Paton et al., 2000). The earliest appearance of group 2.3 was in Germany in 1982 and later on in Italy, France, Belgium, Great Britain, Austria, Switzerland, Hungary, Czech Republic, Poland, and Slovak Republic. Viruses of subgroup 2.2 have been found in Central Europe, in Austria, Czech Republic, Italy, Germany, Romania and Hungary, from 1985 onwards (Greiser-Wilke et al., 1998), whereas subgroup 2.1 viruses have been only sporadically reported in Europe (Paton et al., 2000). Subgroups 2.2 and 2.3 were commonly derived from wild boars (Paton et al., 2000). Recently, genetic typing of viruses isolated in Eastern Europe countries has shown that, with the exception of two isolates (one from Croatia belonging to 2.1. and the other one from Macedonia to 2.2 subgroup), all isolates were members of subgroup 2.3 (Blome et al., 2010). 5'NCR sequences analysis of all available 2.3. Eastern European isolates have shown clustering in two clades designated as 2.3.1 and 2.3.2 (Blome et al., 2010). The 2.3.1. clade was composed of isolates from Bulgaria, collected during the period 1997-2007, Germany, Poland, Czech Republic, Slovak Republic and Croatia (Blome et al., 2010). All Romanian isolates were in clade 2.3.2., as well as isolates from Croatia (period 2006-2007), Kosovo and Austria (Blome et al., 2010).

Clinical diagnosis of CSF is very difficult particularly in older animals and when the involved virus strain is of low or moderate virulence. Many other diseases having similar symptoms (Done et al., 2000) make clinical diagnosis of CSF additionally difficult and prolonge the time until the disease is confirmed (Paton, 2002). Because of the lack of pathognomonic clinical signs of CSF, laboratory confirmation of the disease is necessary, even for secondary cases during the large outbreaks (Paton and Greiser-Wilke, 2003).

Laboratory diagnosis based on virus isolation $(\mathrm{VI})$ or the detection of viral antigen, specific antibodies and viral RNA is essential for accurate confirmation of 
suspicious cases (Van Oirschot et al., 1999). CSFV detection, regardless the clinical stage of infection, from early infection, during the incubation and all along the clinical phase, is possible using reverse-transcription PCR (RT-PCR) and realtime RT-PCR (Handel et al., 2004). Furthermore, detection of viral RNA is possible regardless the course of CSF, even when mild forms of CSF occur, as well as at the seroconversion phase, in the presence of antibodies (Handel et al., 2004). Assays for the detection of CSFV genome are mainly based on 5'-NCR (Barlic-Maganja and Grom, 2001) and 3'-NCR (Vilcek et al., 1999) sequences as well as genes for $N^{\text {pro }}, C, E^{\text {rns }}$ (Barlic-Maganja and Grom, 2001), E2 (Vilcek et al., 1996) and NS5B proteins (Vilcek et al., 1996). Also, assays for the differentiation of CSFV from other Pestiviruses are developed: nested RT-PCR (Katz et al., 1993), restriction analysis (Parchariyanon et al., 1999; Vilcek and Belak, 1998), RT-PCR-ELISA (BarlicMaganja and Grom, 2001) and real time RT-PCR (McGoldrick et al., 1999; Risatti et al., 2003). Currently, real time RT-PCR is being recommended for confirmatory diagnosis in individual animals, as well as for herds surveillance (Handel et al., 2004). Although it is considered that higher RT-PCR sensitivity had been achieved by assays harmonisation, contamination remains the main problem (Paton et al., 2000a). Validation of commercial kits is done according to OIE recommendations. However, a many of the published and in house assays do not provide this documentation (Blome et al., 2006).

Control of CSF in Serbia has been done by $\mathrm{C}$ strain mass vaccination. According to National Directive on Classical Swine Fever (Anonymous, 2009), compulsory vaccination is requested for all piglets 45-60 days of age, gilts and sows at least 15 days before each insemination, and boars every 6 months. During the last decade, 1381 CSF outbreaks were recorded in Serbia, with the peak in 2006 when more than 400 outbreaks were reported (Milicevic et al., 2009).

The main objective of this study was genotyping of 15 CSFV isolates in Serbia between 2006 and 2008 based on the partial nucleotide sequences of the E2 glycoprotein gene and $5{ }^{\prime} \mathrm{NCR}$. In addition, the effectiveness of real time RTPCR for the detection of CSFV from clinical specimens was evaluated.

\section{MATERIAL AND METHODS}

\section{CSFV isolates and sequences}

Tissue samples (15 tonsils and lymph nodes) uniformly representing spatial and temporal CSF occurring during the 2006-2008 were selected for the study.

The reference strains of classical swine fever viruses, genotypes 1.1. (CSF0902/gt1.1.), 1.3. (CSF0653/gt1.3.), 2.1. (CSF0849/gt2.1.), 2.2. (CSF0018/ gt2.2.), 2.3. (CSF0621/gt2.3.), bovine viral diarrhea virus type 1 (C24V) and 2 (UK502643) and border disease virus (Moredun) were used, as well. Sample IDs, including the region virus has been isolated from, the year of isolation, as well as the reference materials data, are given in Table 1. 
Table 1. Detailed description of samples and reference materials

\begin{tabular}{|c|c|}
\hline SAMPLE ID & ORIGIN \\
\hline BELGRADE 2006 & \multirow{15}{*}{ INSTITUTE OF VETERINARY MEDICINE OF SERBIA } \\
\hline BELGRADE 2007 & \\
\hline KRALJEVO 2006 & \\
\hline KRALJEVO 2007 & \\
\hline ZRENJANIN 2006 & \\
\hline JAGODINA 2006 & \\
\hline JAGODINA 2007 & \\
\hline NIS 2006 & \\
\hline NIS 2007 & \\
\hline PANCEVO 2006 & \\
\hline PANCEVO 2007 & \\
\hline POZAREVAC 2006 & \\
\hline SABAC 2006 & \\
\hline SABAC 2007 & \\
\hline ZAJECAR 2008 & \\
\hline CSF gt 1.1. & \multirow{6}{*}{$\begin{array}{l}\text { EU REFERENCE LABORATORY FOR } \\
\text { CLASSICAL SWINE FEVER, INSTITUT FÜR VIROLOGIE, } \\
\text { HANNOVER, GERMANY }\end{array}$} \\
\hline CSF gt 1.3. & \\
\hline CSF gt 2.1 & \\
\hline CSF gt 2.2 & \\
\hline CSF gt 2.3. & \\
\hline BDV & \\
\hline BVDV 1 & \multirow{2}{*}{$\begin{array}{l}\text { OIE REF.LAB FOR BVD } \\
\text { (Veterinary Laboratories Agency: VLA Weybridge) }\end{array}$} \\
\hline BVDV 2 & \\
\hline
\end{tabular}

Viral RNA isolation

Tissues samples were prepared as $10 \%$ homogenates in PBS. Suspensions were centrifuged for 10 minutes at $2000 \mathrm{~g}$ and supernatants were used for RNA extraction.

Viral RNA was isolated using the commercial kit, QIAamp® Viral RNA Mini Kit (Qiagen, USA) according to the manufacturer's recommendations from $140 \mu \mathrm{L}$ of supernatant.

Reverse transcriptase-polymerase chain reaction (RT-PCR)

For phylogenetic analysis, two regions, 150 nt fragment of the $5^{\prime}$ NTR and $190 \mathrm{nt}$ fragment of the E2 gene, were amplified using previously published primers (Paton et al., 2000) in concentration $0.6 \mathrm{pmol} / \mu \mathrm{L}$. Both RT-PCR were run as $50 \mu \mathrm{L}$ reactions using the Qiagen OneStep RT-PCR Kit (Qiagen, USA) according to the manufacturer's specifications, in an Eppendorf Master Cycler 
(Eppendorf, USA). Thermocycling was performed under following conditions: $5^{\circ} \mathrm{C}$ for $30 \mathrm{~min}$; initial denaturation at $95^{\circ} \mathrm{C}$ for $15 \mathrm{~min}$, followed by 35 cycles of denaturation at $95^{\circ} \mathrm{C}$ for $45 \mathrm{sec} ; 1 \mathrm{~min}$ of annealing at $50^{\circ} \mathrm{C}\left(5^{\prime} \mathrm{NCR}\right) / 55^{\circ} \mathrm{C}$ (E2), 1 min and extension for $1 \mathrm{~min}$ at $72^{\circ} \mathrm{C}$,) with a 5 min final elongation step at $72^{\circ} \mathrm{C}$. Products were separated on a $2 \%$ agarose gel stained with ethidium bromide.

TaqMan real time RT-PCR was carried out as $25 \mu \mathrm{lL}$ reaction using TaqMan ${ }^{\circledR}$ One-Step RT-PCR Master Mix Reagents Kit (Applied Biosystems, Warrington, UK) according to the manufacturer's instructions. Primers and probe, previously published by Hoffmann et al. (2005), were used in concentrations of $250 \mathrm{nmol} / \mu \mathrm{L}$ and $50 \mathrm{nmol} / \mu \mathrm{L}$, respectively. The PCR program was set up as follows: $48^{\circ} \mathrm{C} 30$ min, $95^{\circ}$ for 10 min followed by 50 two step cycles $\left(94^{\circ} \mathrm{C}\right.$ for $15 \mathrm{sec} ; 1 \mathrm{~min}$ at $\left.60^{\circ} \mathrm{C}\right)$.

A single tube SYBR Green real time RT-PCR assay in a $25 \mu \mathrm{L}$ reaction mix was performed, using the SYBR ${ }^{\circledR}$ Green PCR Master Mix and RT-PCR Reagents, according to manufacturer's recommendations (Applied Biosystems, Warrington, U.K) including set of primers (Vilcek et al., 1994), in concentrations $250 \mathrm{nmol} / \mu \mathrm{L}$. The thermo profile was set up as follows: $48^{\circ} \mathrm{C}$ for $30 \mathrm{~min}$; $10 \mathrm{~min}$ at $95^{\circ} \mathrm{C}, 50$ two step cycles $\left(95^{\circ} \mathrm{C}\right.$ for $15 \mathrm{sec} ; 1 \mathrm{~min}$ at $\left.60^{\circ} \mathrm{C}\right)$. RT-PCR was coupled with the highresolution melting analysis, in order to determine specific amplification.

\section{Nucleotide sequencing and sequence analysis}

The amplicons were purified using the QIAquick PCR Purification Kit (Qiagen) according to manufacturer's instructions. Purified products were cyclesequenced in both directions using Big Dye Terminators (Applied Biosystems, Warrington, UK) in ABI 310 genetic analyzer (Applied Biosystem, Warrington, UK). Distances of sequences were calculated by the Kimura-2 parameter method and trees were generated by Neighbor Joining using MEGA 4.0 software (Tamura et al., 2007).

\section{RESULTS}

Comparing partial E2 and 5'NCR nucleotide sequences of Serbian CSFV isolates and reference CSF viruses and other Pestiviruses, it was shown that all viruses from Serbia belonged to 2.3 subgroup. Genotyping was based on $150 \mathrm{nt}$ partial E2 encoding gene and 190 nt 5' NCR. Phylogenetic tree was constructed using Neighbor Joining method, for both analyzed regions (Figures 1 and 2).

Differences rate for E2 region ranged from 0.000 (Jagodina 2006 - Nis 2006 - Nis 2007 - Pancevo 2007 - Sabac 2007 - Kraljevo 2007) to 0.069 per nucleotide site (Pozarevac 2006 - Sabac 2006). Overall distance between E2 sequences was 0.021 per nucleotide site. Even less variable results were observed for 5'NCR region where overall distance was 0.07 .

Based on identical E2 and 5'NCR sequences of some isolates (Jagodina 2006 - Kraljevo 2007 - Nis - 2007 - Sabac 2007) the same source of infection can be considered. But some isolates identical in 5'NCR were the most divergent in E2 region (Pozarevac 2006 - Sabac 2006) additionally confirming that for molecular epidemiology sequence analysis and genotyping based on of one single region is not enough. 
Milićević Vesna et al.: Detection and genotyping of classical swine fever virus isolates in Serbia

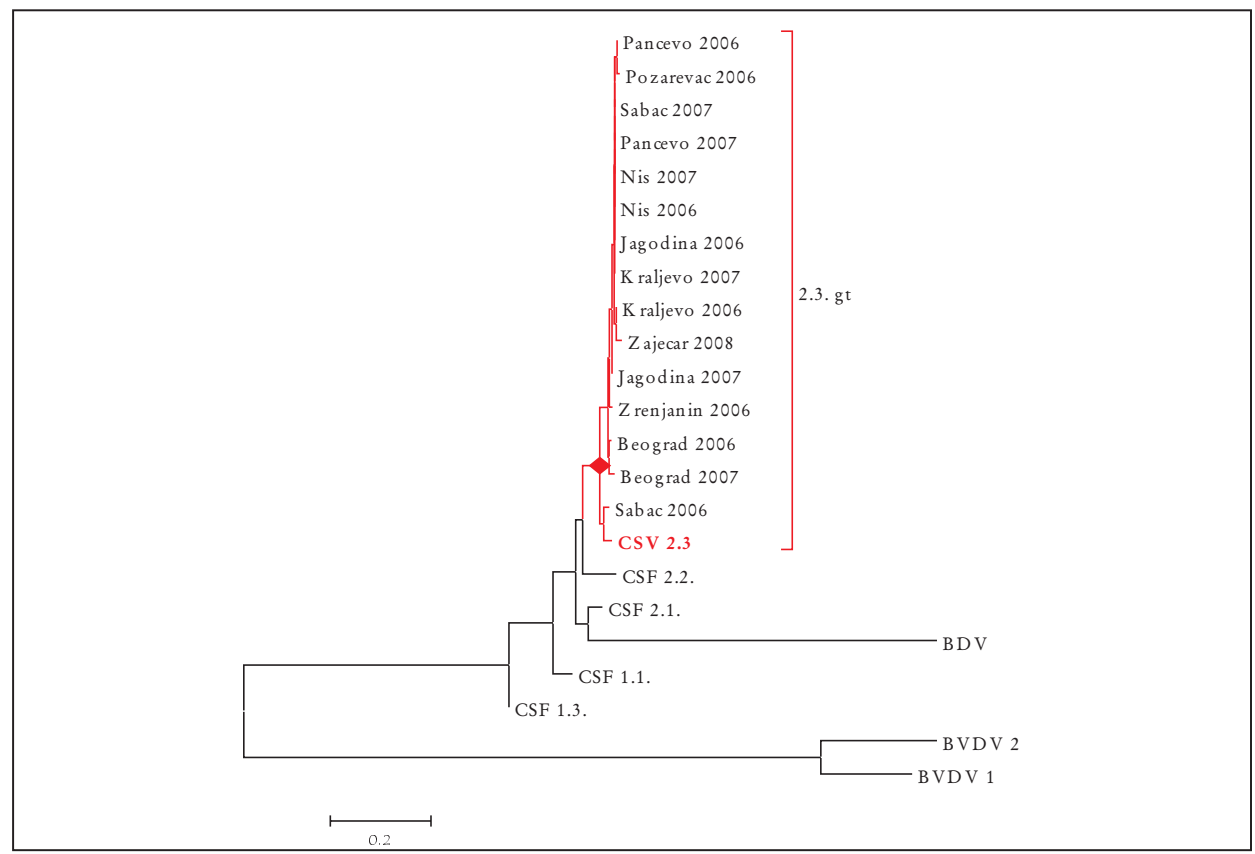

Figure 1. Phylogenetic tree constructed for partial E2 gene, Neighbor-Joining method

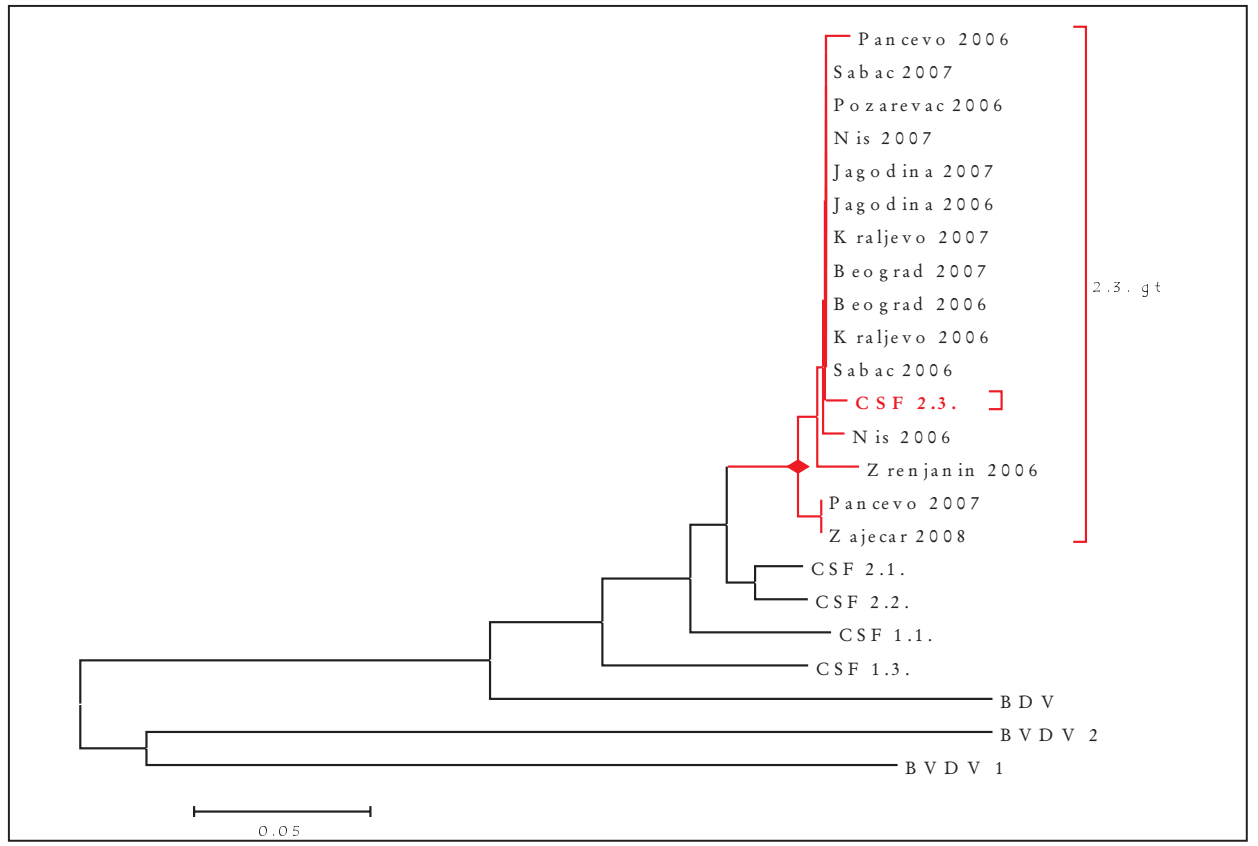

Figure 2. Phylogenetic tree constructed for 5'NCR, Neighbor-Joining method 


\section{DISCUSSION}

Evaluating applicability of recommended real time RT-PCR assays with Serbian isolates, it was shown that all target nucleotide sequences were detected using TaqMan and SYBR Green. Positive amplification was observed with reference strains of classical swine fever virus, while other Pestiviruses were detected only by panpesti SYBR Green real time RT-PCR.

After 2000 CSF situation in Serbia become very difficult since CSFV was spread throughout the whole country. The most common transmission rout was illegal trade (Milicevic et al., 2009). Additionally, vaccination coverage was very low due to the poor economic status of pig holders and their inability to cover vaccination costs. After 2006. vaccination has been funded by the Budget of the Republic of Serbia and since then CSF incidence has been decreasing continuously. The last outbreak was reported in 2010 (World Organization for Animal Health-OIE). During this period, the large economic loss was estimated at 137 million euros (Milicevic et al., 2009).

The real time RT-PCR is a powerful diagnostic tool suitable for the detection of CSFV infection in animals. In order to obtain the most reliable results by real time RT-PCR method, it is necessary to analyze as many as possible genome sequences of the CSF virus which have been circulating in the local swine population. Although CSF in Serbia was common in the past, very few sequences are available in gene banks which imply that assays currently in use have to be evaluated with local isolates. While some assays are recommended by CSF CRL, submission of Serbian isolates to CSF CRL for confirmatory and further testing was not common practice in the past and validation of these assays should not be accepted a priori.

By conducting the program of CSF eradication, Serbia approaches the moment when vaccination against CSFV will be ceased. Before the late phase of eradication, when the chronic course of the disease and infections with low virulent strains are common, it is very important that the evaluation of different diagnostic methods is completed. To support very difficult clinical diagnosis in this phase, laboratory diagnostic has to be most accurate. Assays evaluated in this study have been chosen in order to harmonize diagnostic procedures of CSF with standards applied in EU countries. Using both assays we were able to detect local CSF viruses which circulated in Serbia in the last five years during the intensive vaccination campaign against CSF. In order to maintain a reliable diagnostic of CSF, it is necessary to monitor on the virus genome for new CSF isolates in Serbia, as well as in other countries, and to confirm each negative result by other tests due to viral mutagenic potential. Moreover, since in the next phase of the disease eradication, vaccination against CSF will be stopped, it would be interesting to follow the future expansion of this virus and its genome changes in susceptible (unvaccinated) swine populations.

ACKNOWLEDGEMENTS:

This work was supported by the Ministry of Science and Technological Development of the Republic of Serbia, grants TR 31075 and TR 31088. 
Address for correspondence:

Vesna Milicevic

Institute of Veterinary Medicine of Serbia

Vojvode Toze 14

11000 Beograd, Serbia

mvekac@yahoo.com

\section{REFERENCES}

1. Anonymous, 2009, Pravilnik o utvrđivanju mera za rano otkrivanje, dijagnostiku, sprecavanje sirenja, suzbijanje i iskorenjivanje zarazne bolesti klasicne kuge svinja, kao i nacinu njihovog sprovođenja, 2009, SI. Glasnik Republike Srbije.

2. Barlic-Maganja D, Grom J, 2001, Highly sensitive one-tube RT-PCR and microplate hybridisation assay for the detection and for the discrimination of classical swine fever virus from other pestiviruses, J Virol Meth, 95, 101-10.

3. Blome S, Meindl-Böhmer A, Loeffen W, Thuer B, Moennig V, 2006, Assessment of classical swine fever diagnostics and vaccine performance, Rev Sci Tech Off Int Epiz, 25, 3, 1025-38.

4. Blome S, Grotha I, Moennig, V, Greiser-Wilke I, 2010, Classical swine fever virus in South-Eastern Europe - Retrospective analysis of the disease situation and molecular epidemiology, Vet Microbiol, 146, 3-4, 276-84.

5. Dewulf J, Laevens H, Koenen F, Mintiens K, de Kruif A, 2001, An experimental infection with classical swine fever virus in pregnant sows: transmission of the virus, course of the disease, antibody response and effect on gestation, $J$ Vet Med B Infect Dis Vet Public Health, 48, 583-91.

6. Done SH, Potter RA, Gresham ACJ, Chennells DG, 2000, Post weaning Multisystemic wasting syndrome and Porcine Dermatitis and Nephropathy Syndrome - two new pig diseases: a single view of the clinical indicators, Practice, 23, 14-21.

7. Edwards S, 2000, Survival and inactivation of classical swine fever virus, Vet Microbiol, 73, 175-81.

8. Greiser-Wilke I, Depner K, Fritzemeier J, Haas L, Moennig V, 1998, Application of a computer program for genetic typing of classical swine fever virus isolates from Germany, J Virol Meth, 75, 2, 141-50.

9. Greiser-Wilke I, Fritzemeier J, Koenen F, Vanderhallen H, Rutili D, De Mia GM et al., 2000, Molecular epidemiology of a large classical swine fever epidemic in the European Union in 1997-1998, Vet Microbiol, 77, 17-27.

10. Handel K, Kehler H, Hills K, Pasick J, 2004, Comparison of reverse transcriptase-polymerase chain reaction, virus isolation, and immunoperoxidase assays for detecting pigs infected with low, moderate, and high virulent strains of classical swine fever virus, $J$ Vet Diagn Invest, 16, 2, 132 8.

11. Heinz FX, Collet M S, Purcell RH, Gould EA, Howard CR, Houghton M et al., 2000, In: Family Flaviviridae. Virus Taxonomy. Classifcation and Nomenclature of Viruses. Seventh Report of the International Committee on Taxonomy of Viruses. (van Regenmortel, M.H.V., C.M. Fauquet, D.H.L. Bishop, E.B. Carstens, M.K. Estes, S.M. Lemon, J. Maniloff, M.A. Mayo, D.J. Mc Geoch, C.R. Pringle, R.B. Wickner, editors, Academic Press, San Diego, San Francisco, New York, Boston, London, Sydney, Tokyo, 859-78.

12. Hoffmann B, Beer M, Schelp C, Schirrmeier H, Depner K, 2005, Validation of a real time RT-PCR assay for sensitive and specific detection of Classical swine fever, J Virol Meth, 130, 1-2, 36-44.

13. Katz JB, Ridpath JF, Bolin SR, 1993, Presumptive diagnostic differentiation of hog cholera virus from bovine viral diarrhea and border disease viruses by using a cDNA nested-amplification approach J Clin Microbiol, 31, 565-8.

14. McGoldrick A, Bensaude E, Ibata G, Sharp G, Paton DJ, 1999, Closed one-tube reverse transcription nested polymerase chain reaction for the detection of pestiviral RNA with fluorescent probes, $J$ Virol Meth, 79, 85-95.

15. Meyers G, Rumenapf T, Thiel HJ, 1989, Molecular cloning and nucleotide sequence of the genome of hog cholera virus, Virology ,171, 555-67. 
16. Milicevic V, Stanojevic S, Maksimovic J, Radosavljevic V, Stanojevic S, Milosevic B, 2009, Klasicna kuga svinja u Srbiji, 8. kongres veterinara Srbije, Beograd, Zbornik referata, 251-61.

17. Moennig V, Plagemann P GW, 1992, The pestiviruses, Adv Virus Res, 41, 53-98.

18. Parchariyanon S, Inui K, Pinyochon W, Damrongwatanapokin S, Takahashi E, 2000, Genetic grouping of classical swine fever virus by restriction fragment length polymorphism of the E2 gene. J Virol Meth, 87, 145-9.

19. Paton DJ, McGoldrick A, Greiser-Wilke I, Parchariyanon S, Song, JY, Liou PP et al., 2000, Genetic typing of classical swine fever virus, Vet Microbiol, 73, 137-57.

20. Paton DJ, McGoldrick A, Belak S, Mittelholzer C, Koenen F, Vanderhallen H et al., 2000a, Classical swine fever virus: a ring test to evaluate RT-PCR detection methods, Vet Microbiol, 73, 159-74.

21. Paton D, 2002, The reappearance of classical swine fever in England in 2000, In: Trends in Emerging Viral Infections of Swine, lowa State Press, Ames lowa, 153-8.

22. Paton DJ, Greiser-Wilke I, 2003, Classical swine fever - an update, Res Vet Sci, 75, 169-78.

23. Risatti GR, Callahan JD, Nelson WM, Borca MV, 2003, Rapid detection of classical swine fever virus by a portable real-time reverse transcriptase PCR assay, J Clin Microbiol, 41, 500-5.

24. Tamura K, Dudley J, Nei M, Kumar S, 2007, MEGA4: Molecular evolutionary genetics analysis (MEGA) software version 4.0., Mol Biol and Evolution, 24, 1596-9.

25. Thiel H, Plagenunn PGW, Moennig V, 1996, Pestivirus, In: Ficldi BN, Knipe BM, and Howley PM, editors, Fields' Virology, New York, Lippincott-Raven publisher, 1059-73.

26. Van Oirschot JT, 1999, Classical Swine Fever, In: Straw BE, D'Allaire S, Mengeling WL, and Taylor DJ, editors, Diseases of Swine, 8th Edn. lowa State University Press, Ames, lowa, 159-72.

27. Vilcek S, Herring AJ, Herring AJ, Nettleton PF, Lowings JP, Paton DJ, 1994, Pestiviruses isolated from pigs, cattle and sheep can be allocated into at least three genogroups using polymerase chain reaction and restriction endonuclease analysis, Arch Virology, 136, 309-23.

28. Vilcek S, Stadejek T, Ballagi-Pordany A, Lowings JP, Paton DJ, Belak S, 1996, Genetic variability of classical swine fever virus, Virus Res, 43, 137-47.

29. Vilcek S, Belak S, 1998, Classical swine fever virus: discrimination between vaccine strains and European field viruses by restriction endonuclease cleavage of PCR amplicons, Acta Vet Scand, 39, 395-400.

30. Vilcek S, Paton D, Lowings P, Bjorklund H, Nettleton P, Belak S, 1999, Genetic analysis of pestiviruses at the $3^{\prime}$ end of the genome, Vir Genes, 18, 107-14.

\title{
DETEKCIJA I GENOTIPIZACIJA IZOLATA VIRUSA KLASIČNE KUGE SVINJA U SRBIJI
}

\author{
MILIĆEVIĆ VESNA, RADOJIČIĆ SONJA, VALČIĆ AM, IVOVIĆ V, \\ MAKSIMOVIĆ-ZORIĆ JELENA i RADOSAVLJEVIĆ V
}

\begin{abstract}
SADRŽAJ
Klasična kuga svinja (CSF) je visoko kontagiozno oboljenje svinja koje dovodi do značajnih ekonomskih gubitaka širom sveta. Na osnovu genetske strukture, virus klasične kuge svinja podeljen je u tri genogrupe, od kojih svaka ima tri ili četiri podgrupe. Nedostaju podaci o tome koji genotipovi virusa klasične kuge svinja na teritotoriji Republike Srbije cirkulišu u prijemčivoj populaciji. Sekvencioniranjem dela E2 gena i 5'nekodirajućeg regiona (NCR) 15 izolata virusa
\end{abstract}


klasične kuge svinja prikupljenih u periodu od 2006-2008 godine, poreklom od domaćih svinja, dokazano je da svi pripadaju genetskoj grupi 2.3. Uz to, dokazano je i da je upotrebom dva najčešće korišćena real time RT-PCR protokola moguće detektovati sve lokalne izolate virusa klasične kuge svinja koji cirkulišu u Srbiji poslednjih godina, u kojoj se uporedo vršila i intenzivna vakcinacija protiv ove bolesti. 